\title{
PENGARUH SUBTITUSI TEPUNG TERIGU DENGAN TEPUNG SUKUN (Artocarpus altilis) TERHADAP MUTU KIMIA KUE SEMPRONG
}

\section{EFFECT OF SUBTITUTION OF WHEAT FLOUR WITH Breadfruit (Artocarpus altilis) ON QUALITY CHEMICAL CAKE SEMPRONG}

\author{
Fitriani Basrin $^{1 *}$ \\ ${ }^{1}$ Program Studi Program Studi Teknologi Pengolahan Hasil Laut, Politeknik Palu \\ Jln. Sinarkemuning 1 No. 1A Palu 94118 Sulawesi Tengah Indonesia
}

\begin{abstract}
ABSTRAK
Sukun (Artocarpus altilis) merupakan salah satu tanaman penghasil buah utama dari keluarga Moraceae. Tanaman ini sudah lama dibudidayakan oleh masyarakat Indonesia bahkan di beberapa Negara di kawasan Pasifik seperti Fiji, Tahiti, Kepulauan Samoa, dan Hawai, buah sukun telah dimanfaatkan sebagai makanan pokok tradisional. Konsumsi buah sukun umumnya masih terbatas sebagai makanan ringan dan sayur serta salah satu sumber bahan pangan alternatif, buah sukun terbukti memiliki kandungan gizi cukup tinggi. Tujuan dalam penelitian ini adalah untuk mengetahui pengaruh subtitusi tepung terigu dengan tepung sukun (Artocarpus altilis) terhadap mutu kimia kue semprong atau egg roll. Rancangan perlakuan pada penelitian subtitusi tepung terigu dengan tepung Sukun (Artocarpus altilis) terhadap mutu kimia kue semprong yaitu: P0 (100 gram tepung terigu), P1 (75 gram tepung terigu +25 gram tepung sukun), P2 (50 gram tepung terigu +50 gram tepung sukun), P3 (75 gram tepung terigu +25 gram tepung sukun), dan P4 (100 gram tepung sukun). Rancangan percobaan yang digunakan adalah Rancangan Acak Legkap (RAL) dengan 5 perlakuan dan 4 ulangan. Hasil uji analisis proksimat yang meliputi kadar air, abu, lemak, protein dan karbohidrat, dengan nilai rata-rata kadar air $3.50 \%$, kadar abu $1.07 \%$, kadar lemak 26,97\%, kadar protein $4.21 \%$, dan kadar karbohidrat $63.88 \%$.
\end{abstract}

Kata kunci: semprong, analisis proksimat, subtitusi, tepung terigu, sukun (artocarpus altilis)

\begin{abstract}
Breadfruit (Artocarpus altilis) is one of the main fruit producing plants of the Moraceae family. This plant has long been cultivated by the people of Indonesia and even in several countries in the Pacific region such as Fiji, Tahiti, the Samoan Islands, and Hawaii, breadfruit has been used as a traditional staple food. The consumption of breadfruit is generally still limited as a snack and a vegetable and as an alternative food source, breadfruit is proven to have a high nutritional content. The purpose of this study was to determine the effect of substitution of wheat flour with breadfruit (Artocarpus altilis) on the chemical quality of semprong cake or egg roll. The treatment design in this research on the substitution of wheat flour with breadfruit flour (Artocarpus altilis) on the chemical quality of semprong cakes, namely: P0 (100 grams of wheat flour), P1 (75 grams of wheat flour +25 grams of breadfruit flour), $P 2$ (50 grams of wheat flour +50 grams of breadfruit flour), P3 (75 grams of wheat flour +25 grams of breadfruit flour), and P4 (100 grams of breadfruit flour). The experimental design used was a randomized randomized design (CRD) with 5 treatments and 4 replications. The results of the proximate analysis test included moisture, ash, fat, protein and carbohydrate content, with an average value of $3.50 \%$ water content, $1.07 \%$ ash content, $26.97 \%$ fat content, $4.21 \%$ protein content, and $63.88 \%$ carbohydrate content.
\end{abstract}

Keywords: semprong, proximate analysis, substitution, wheat flour, breadfruit (artocarpus altilis) Pendahuluan

\footnotetext{
${ }^{*}$ Penulis Korespondensi.

E-mail: fitrianibasrin014@gmail.com

HP : +62 852-5665-2955
}

Indonesia merupakan negara yang banyak melakukan impor tepung terigu dari negara Timur Tengah seperti Turki, Srilanka, dan Australia. Harga tepung terigu yang berada di 
pasaran merupakan harga subsidi yang selebihnya harus ditanggung pemerintah Indonesia, harga tepung terigu sangat tinggi di atas harga pasaran. Untuk memenuhi kebutuhan tepung terigu dan mengurangi ketergantungan akan impor, pemerintah dan masyarakat berupaya mencari alternatif bahan pangan lokal seperti buah sukun yang dapat dijadikan tepung (Lubis, $d k k, 2015)$.

Penyebaran tanaman sukun sangat meluas di kepulauan Indonesia, tanaman sukun banyak terdapat di daerah Sumatera, Jawa, Nusa Tenggara, Sulawesi, Maluku, dan Irian. Pemanfaatan utama tanaman sukun adalah buahnya. Buah sukun yang diperoleh dari tanaman sukun jenis Artocarpus altilis bisa dimanfaatkan sebagai makanan pokok tradisional, tepung, gaplek, maupun sebagai makanan ringan (Prastyono, $d k k, 2014$ ).

Pengolahan sukun menjadi tepung merupakan alternatif cara pengolahan yang memiliki beberapa keunggulan yaitu meningkatkan daya simpan dan memudahkan pengolahan bahan bakunya. Tepung sukun selain mudah diolah menjadi produk lain juga kandungan gizi relatif tak berubah.

Untuk meningkatkan nilai tambah, buah sukun dapat diolah menjadi tepung yang selanjutnya diolah menjadi beraneka macam makanan seperti egg roll, pastel, cake, mie basah, lapis. Kue semprong atau egg roll merupakan makanan kecil yang kering. Aroma khas egg roll berasal dari bahan-bahan yang digunakan seperti telur, margarin, susu dan vanili. Sesuai dengan namanya, egg roll dibuat dengan menggunakan banyak telur dan berbahan baku tepung terigu yang biasanya disubtitusikan dengan tepung sukun.

Kue semprong atau egg roll merupakan salah satu makanan tradisional populer bagi masyarakat Indonesia. Kue semprong yang dikehendaki konsumen umumnya yang memiliki rasa yang tidak terlalu manis, gurih, aroma wangi, renyah, teksturnya tidak terlalu keras maupun lunak, tekstur permukaan yang halus dengan warna kuning kecoklatan yang menarik (Harijono, $d k k, 2012$ ).

Berdasarkan uraian diatas, buah sukun sangatlah penting dijadikan tepung sukun sebagai bahan penelitian karena memiliki beberapa keunggulan mulai dari daya simpan dan dapat memudahkan pengolahan bahan bakunya. Maka dari itu peneliti tertarik untuk membuat sebuah penelitian tentang subtitusi tepung terigu dengan tepung sukun (Artocarpus altilis) terhadap mutu kimia kue semprong.

\section{Tujuan dan Manfaat Penelitian}

Tujuan dalam penelitian ini adalah untuk mengetahui pengaruh subtitusi tepung terigu dengan tepung sukun (Artocarpus altilis) terhadap mutu kimia kue semprong atau egg roll.

Adapun manfaat penelitian ini adalah:

1. Dapat menunjang program pemerintah dalam diversifikasi pangan.

2. Dapat menyediakan kebutuhan bahan kue dengan produksi pangan lokal.

\section{Metode Penelitian}

\section{Waktu dan Tempat}

Penelitian ini dilaksanakan pada bulan Juli 2018 dan Januari 2019, di Laboratorium Terapan Teknologi Pengolahan Hasil Bumi Politeknik Palu dan Laboratorium MIPA Universitas Tadulako.

\section{Alat dan Bahan \\ Peralatan yang digunakan dalam penelitian ini adalah pisau, plastik, mixer, baskom sedang atau mangkuk, timbangan analitik, sendok, spatula, kompor, panggangan (cetakan egg roll) dan talang. \\ Sedangkan bahan-bahan yang digunakan pada penelitian ini adalah tepung terigu, tepung tapioka, tepung sukun, gula pasir, margarin, telur, vanili, ovalet dan butter.}

\section{Metode}

Penelitian ini menggunakan Rancangan Acak Lengkap (RAL) dengan perlakuan subtitusi tepung terigu dengan tepung sukun.

Adapun formulasi tepung terigu dan tepung sukun yaitu:

$\mathrm{P}_{0}: 100$ gram TT

$\mathrm{P}_{1}: 75$ gram $\mathrm{TT}+25$ gram TS

$\mathrm{P}_{2}: 50$ gram $\mathrm{TT}+50$ gram $\mathrm{TS}$

$\mathrm{P}_{3}: 25$ gram $\mathrm{TT}+75$ gram TS

$\mathrm{P}_{4}: 100$ gram TS

Perlakuan diulang sebanyak 4 kali, sehingga terdapat 20 unit percobaan. Pengacakan perlakuan dilakukan langsung terhadap 20 unit percobaan.

\section{Pengamatan}

Parameter yang diamati dalam penelitian ini adalah kadar proksimat (kadar air, kadar abu, protein, lemak, karbohidrat). 
Kadar Air Total Metode Thermogravimetri

a) Cawan dikeringkan terlebih dahulu selama 1 jam dalam oven pada suhu $105^{\circ} \mathrm{C}$, lalu didinginkan dalam desikator selama $1 / 2$ jam dan kemudian beratnya ditimbang (Wo).

b) Sampel ditimbang seberat 5 gram (Ws), dimasukkan ke dalam cawan, kemudian dimasukkan ke dalam oven selama 3 jam pada suhu $105^{\circ} \mathrm{C}$, lalu didinginkan dalam desikator selama 1 jam dan timbang.

c) Masukkan kembali sampel ke dalam oven selama 1 jam pada suhu $105^{\circ} \mathrm{C}$, lalu didinginkan dalam desikator selama $1 / 2$ jam dan ditimbang.

d) Ulangi pemanasan dan penimbangan hingga diperoleh bobot tetap (Wi).

Adapun rumus penentuan kadar air total sebagai berikut:

$$
\text { Kadar Air }(\%)=\frac{W s-(W i-W o)}{W s} \times 100 \%
$$

Keterangan :

Ws = bobot sampel sebelum dioven (gram)

$\mathrm{Wi}=$ bobot sampel + cawan sesudah dioven (gram)

Wo = bobot cawan kosong (gram)

Kadar Abu Metode dry Ashing (Hafiludin, 2011)

Penentuan kadar abu dilakukan dengan metode pengabuan kering (dry ashing). Prinsip analisis ini adalah mengoksidasi semua zat organik pada suhu tinggi (sekitar $550{ }^{\circ} \mathrm{C}$ ), kemudian dilakukan penimbangan zat yang tertinggal setelah proses pembakaran tersebut.

Cawan yang akan digunakan dikeringkan terlebih dahulu 30 menit atau sampai didapat berat tetap dalam oven pada suhu $100-105^{\circ} \mathrm{C}$. Setelah itu didinginkan dalam desikator selama 30 menit lalu ditimbang (B1). Sampel sebanyak 5 gram dimasukkan dalam cawan yang telah diketahui beratnya, kemudian dibakar diatas bunsen atau kompor listrik sampai tidak berasap. Setelah itu dimasukkan dalam tanur pengabuan, kemudian dibakar pada suhu $400^{\circ} \mathrm{C}$ sampai didapat abu berwarna abu-abu atau sampel beratnya tetap. Kemudian suhu tanur dinaikkan sampai $550^{\circ} \mathrm{C}$ selama $12-24$ jam. Kemudian sampel didinginkan dalam desikator selama 30 menit lalu ditimbang (B2). Perhitungan kadar abu adalah sebagai berikut:

$$
\text { Kadar abu }(\%)=\frac{\text { B2-B1 }}{\text { berat sampel }} \times 100 \%
$$

\section{Kadar Protein Metode Spektrofotometri}

a) Timbang sampel sebanyak 0,5 gram, kemudian masukkan ke dalam Erlenmeyer $250 \mathrm{ml}$. b) Tambahkan larutan $\mathrm{NaOH} 1 \mathrm{M}$ sebanyak $25 \mathrm{ml}$, lalu dikocok di atas mesin agitasi selama 1 jam.

c) Saring campuran, lalu ukur serapanya pada panjang gelombang $(\lambda) 280 \mathrm{~nm}$ dan $260 \mathrm{~nm}$ menggunakan spektrofotometer UV-VIS.

Adapun rumus penentuan kadar protein total adalah :

Kadar protein total $(\%)=$

$\frac{\text { A280 } \times \text { f.koreksi } \times \mathrm{Fp} \times 100 \mathrm{~mL}}{\text { berat sampel }(\mathrm{mg})} \times 100 \%$

Keterangan :

$$
\begin{array}{ll}
\text { f.koreksi } & =\mathrm{A}_{280} / \mathrm{A}_{260} \\
\mathrm{Fp} & =\text { factor koreksi }
\end{array}
$$

\section{Kadar Lemak Metode Soxhletasi}

a) Timbang sampel sebanyak $10 \mathrm{~g}$ dan masukkan ke dalam selongsong kertas.

b) Sumbat selongsong yang berisi sampel dengan kapas.

c) Keringkan pada oven pada suhu $80^{\circ} \mathrm{C}$ selama kurang lebih 1 jam, kemudian masukkan kedalam alat soxlet yang dihubungkan dengan labu lemak yang telah dikeringkan dan diketahui bobotnya.(timbang labu sebelum dipakai).

d) Uapkan pelarutnya secara vakum dengan menggunakan rotary vakum evaporator.

e) Keringkan ekstrak lemak dalam oven pengering suhu $105{ }^{\circ} \mathrm{C}$ selama 1 jam.

f) Dinginkan dalam desikator dan timbang hingga bobot tetap.

Adapun rumus penentuan kadar lemak total sebagai berikut:

$$
\begin{aligned}
& \text { Kadar lemak }=\frac{W 1-W 2}{W} \times 100 \% \\
& \text { Keterangan : }
\end{aligned}
$$

$\mathrm{W}=$ bobot sampel awal (gram)

$\mathrm{W} 1=$ bobot labu + sampel sesudah ekstraksi (gram)

W2 = bobot labu kosong (gram)

Kadar Karbohidrat by difference (Santi, dkk, 2012)

Pengukuran kadar karbohidrat total dalam sampel dihitung berdasarkan perhitungan (dalam \%) :

Kadar karbohidrat $(\%)=100 \%-(\mathrm{A}+\mathrm{B}+\mathrm{C}+\mathrm{D})$

Keterangan :

\section{Pelaksanaan}

$$
\begin{aligned}
& \mathrm{A}=\text { Kadar air } \\
& \mathrm{B}=\text { Kadar abu } \\
& \mathrm{C}=\text { Kadar lemak } \\
& \mathrm{D}=\text { Kadar protein }
\end{aligned}
$$

Penelitian ini dilakukan dua tahapan, yaitu pembuatan tepung sukun dan pembuatan 
semprong atau egg roll dengan subtitusi tepung terigu dengan tepung sukun, kemudian hasil kue semprong akan dianalisis kandungan proksimat dari setiap perlakuan.

\section{Pembuatan Tepung Sukun (Artocarpus altilis)}

Pembuatan tepung sukun ada beberapa cara, namun pada prinsipnya adalah sama, secara garis besar adalah dimulai dari pembersihan buah, pengirisan,

pengeringan, penepungan/penggilingan, dan pengayakan. Tepung sukun dikemas dalam kantong plastik, dan disimpan atau siap untuk didistribusikan. Langkah-langkah pembuatan tepung sukun adalah sebagai berikut :

a. Pembersihan buah sukun. Proses pembersihan disini adalah memisahkan buah sukun dari kulit dan kotoran yang menempel dan dicuci hingga bersih.

b. Pengirisan buah sukun. Sukun yang sudah dikupas dibuang bagian tengahnya, kemudian diiris tipis-tipis agar lebih cepat kering pada proses pengeringan.

c. Pengeringan Proses pengeringan bisa dilakukan dengan memanfaatkan sinar matahari. Jika tidak memungkinkan pengeringan dengan sinar matahari bisa menggunakan oven dengan suhu $55-60^{\circ} \mathrm{C}$. Ciri-ciri sukun yang kering jika dipatahkan akan berbunyi klik.

d. Penggilingan Sukun yang sudah benar-benar kering digiling hingga halus.

e. Pengayakan Setelah proses penggilingan tepung sukun diayak menggunakan ayakan dengan ukuran mess 80 (Purwanita, 2013).

Pembuatan Kue Semprong dengan Subtitusi Tepung Terigu dan Tepung Sukun (Artocarpus altilis)

Setelah tahap pertama selesai, dilanjutkan dengan tahap kedua. Pada pembuatan kue semprong ini, diberikan perlakuan subtitusi tepung terigu dengan tepung sukun. Tabel berikut memberikan informasi bahan yang digunakan pada setiap perlakuan.

Tabel 1. Komposisi Kue Semprong (Egg Roll)

\begin{tabular}{|c|c|c|c|c|c|c|c|c|c|}
\hline \multirow{2}{*}{ No } & \multirow{2}{*}{ Pettakun } & Is & $\pi$ & II & Grita & Teling & Orale & Vant & Merpars \\
\hline & & (9) & $(9)$ & (9) & $(0)$ & (atrin) & (5) & (9) & (9) \\
\hline 1 & Po & . & 100 & 100 & 150 & 4 & 4 & 2 & 150 \\
\hline 2 & $n$ & 25 & 73 & 100 & 150 & 4 & 4 & 2 & 150 \\
\hline 3 & P2 & 50 & 30 & 100 & 150 & 4 & 4 & 2 & 150 \\
\hline 4 & p3 & 75 & 25 & 100 & ISO & 4 & 4 & 2 & 150 \\
\hline 5 & $p 4$ & 100 & . & 100 & 150 & 4 & 4 & 2 & 150 \\
\hline
\end{tabular}

Pembuata kue semprong dengan subtitusi tepung terigu dan tepung sukun adalah: Gula, telur, ovalet dikocok hingga putih kaku, lalu tambahkan tepung terigu dan tepung sukun sesuai perlakuan, tepung tapioka, serta vanili pada kocokan telur, aduk perlahan hingga rata. Masukkan margarin cair perlahan ke dalam adonan yang sudah tercampur rata. Aduk kembali hingga rata. Cetakan egg roll atau semprong dipanaskan dengan api kecil. Kemudian lelehkan margarin. Adonan dituang sebanyak 1 sendok teh ke dalam cetakan. Kemudian tutup cetakan dan tunggu hingga adonan berubah warna. Setelah berubah warna gulung semprong segera.

\section{Analisis Data}

Dari data hasil penelitian/pengamatan akan dilanjutkan dengan menghitung menggunakan metode Analisis Of Varians (ANOVA), dan jika hasil pengamatan berpengaruh nyata dan sangat nyata maka dilanjutkan dengan uji beda nyata terkecil (BNT) 0,05 atau $5 \%$.

\section{Hasil dan Pembahasan}

\section{Kadar Air}

Adapun rerata kadar air pada kue semprong dapat dilihat pada gambar 2 berikut.

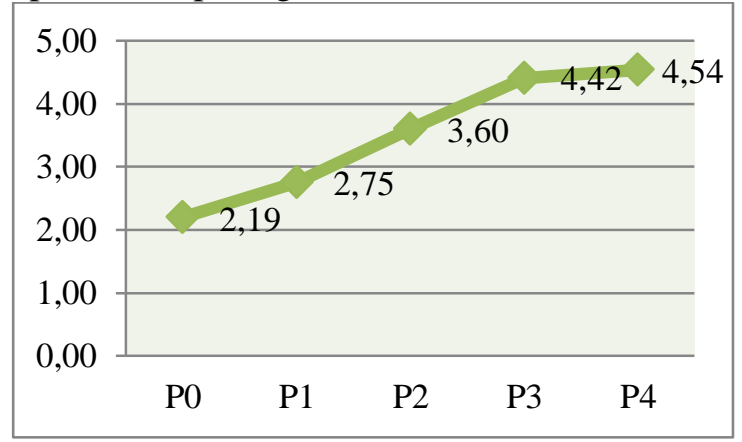

Gambar 2. Diagram Garis Rata-rata Kadar Air Kue Semprong

Kadar air yang diperoleh berkisar antara 2.19-4.54\% hasil kadar air tersebut lebih rendah dari standar kadar air mutu kue kering yang diisyaratakan SNI 01-2973-1992 yaitu sebesar 5\%. Hal ini menunjukan kadar air kue semprong sudah memenuhi standar SNI.

Dari data hasil rata-rata kadar air menunjukan bahwa semakin tinggi tepung sukun yang ditambahkan pada formulasi kue semprong maka nilai rata-ratanya semakin tinggi, berarti formulasi kue semprong pada P4 (100 gram tepung sukun) mempunyai nilai tertinggi dibandingkan dengan $\mathrm{P} 1, \mathrm{P} 2$ dan $\mathrm{P} 3$, namun pada hasil uji BNT 5\% menunjukan bahwa P3 (75 gram tepung sukun) tidak berbeda nyata terhadap P4 (100 gram tepung sukun), tetapi berbeda nyata terhadap P1 (25 gram tepung sukun) dan P2 (50 gram tepung sukun), sedangkan $\mathrm{P} 1$ berbeda nyata terhadap P2, hal ini dikarenakan pada saat 
pembuatan kue semprong semakin tinggi formulasi tepung sukun yang ditambahkan pada setiap perlakuan maka tekstur pada adonan kue semprong menjadi lebih kental sehingga pada proses pembuatannya ketebalan kue semprong tidak menentu karenan tektur ketebalan mempengaruhi kerenyahan pada kue semrpong, semakin renyah kue semprong maka semakin rendah pula kadar airnya.

Faktor lain yang mempengaruhi kadar air yaitu suhu pengovenan yang digunakan tidak stabil sehingga kadar air ikut terpengaruh. Seperti diketahui, pada proses pembuatan tepung sukun adanya tahap pencucian buah sukun setelah dikupas sehingga terjadinya penyerapan karena sukun memiliki kandungan pati, menurut Mutmainah, $d k k, \quad$ (2013) semakin lama perendaman maka semakin tinggi juga kadar air tepung sukun karena semakin lamanya perendaman menyebabkan granula-granula pati mengembang dan banyak menyerap air.

Rakhmah, (2012) beberapa hal yang dapat mempengaruhi kadar air yaitu jenis bahan dan komponen yang ada didalamnya, serta cara dan kondisi pemanggangan seperti alat, suhu, ketebalan bahan dan lama pemanggangan. Ketebalan produk dan suhu pemanggangan mempengaruhi penguapan air pada adonan yang terjadi pada tahap pemanggangan. Menurut Liviawaty, $d k k$, (2014) suatu bahan pangan yang tinggi kadar airnya akan semakin cepat busuk daripada bahan pangan dengan kadar air yang rendah, kadar air juga dapat mempengaruhi penurunan mutu produk. Suatu bahan pangan dapat ditentukan masa daya simpannya dengan menghilangkan sebagian air dalam bahan pangan sehingga mencapai kadar air tertentu.

Proses pengeringan atau pembuatan tepung sukun harus menggunakan suhu secara maksimal sehingga menghasilkan tepung sukun yang baik. Menurut Karim (2016), kandungan air dari suatu bahan pangan perlu diketahui terutama untuk menentukan persentase zat-zat gizi secara keseluruhan. Jumlah kadar air yang terdapat di dalam suatu bahan pangan sangat berpengaruh atas seluruh susunan persentase zat-zat gizi secara keseluruhan. Dengan diketahuinya kandungan air dari suatu bahan pangan, maka dapat diketahui berat kering dari bahan tersebut. kadar air dalam bahan pangan sangat mempengaruhi kualitas dan daya simpan dari bahan pangan tersebut. Oleh karena itu, penentuan kadar air dari suatu bahan pangan sangat penting agar dalam proses pengolahan maupun pendistribusian mendapat penanganan yang tepat, sehingga pada penilitian perlu dilakukannya pengujian kadar air.

\section{Kadar Abu}

Berdasarkan hasil penelitian diperoleh kadar abu kue semprong berkisar antara $0.66 \%$ sampai dengan $1.24 \%$. Gambar 3 menunjukkan rerata kadar abu yang terdapat pada kue semprong.

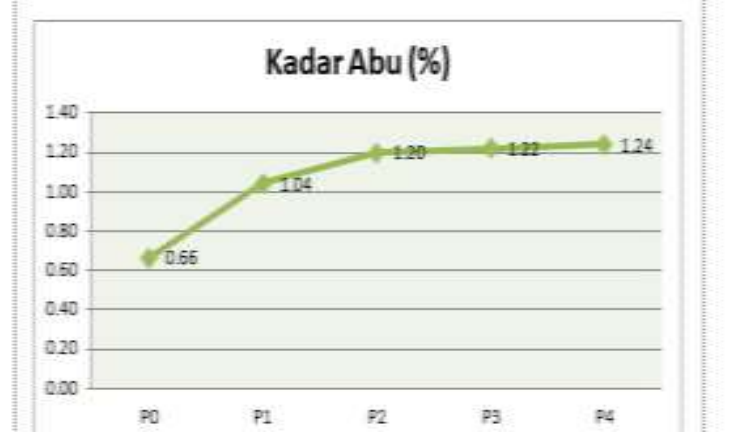

Gambar 3. Diagram Garis Rata-rata Kadar Abu Kue Semprong

Kadar abu yang diperoleh berkisar antara 0.66-1.24\% hasil kadar abu tersebut lebih rendah dari standar kadar abu mutu kue kering yang diisyaratakan SNI 01-2973-1992 yaitu sebesar $2 \%$. Hal ini menunjukan kadar abu kue semprong sudah memenuhi standar SNI.

Hasil Penelitian menunjukkan kadar abu pada kue semprong yang disubstitusi dengan tepung sukun mengalami peningkatan seiring dengan panmabahn formulasinya, yaitu nilai kadar abu tertinggi ada pada P4 (100 gram tepung sukun). Pada hasil uji BNT 5\% (lampiran 2c) menunjukan bahwa $P 2$ (50 gram tepung sukun), tidak berbeda nyata terhadap P3 (75 gram tepung sukun), dan P4 (100 gram tepugn sukun), tetapi berbeda nyata dengan P1 (25 gram tepung sukun). Kandungan kadar abu ini dipengaruhi oleh adanya kandungan mineral yang terkandung pada tepung sukun, jika dilihat pada kandungan gizi tepung sukun (tabel 3) kandungan mineralnya cukup tinggi sehingga pada perlakuan P4 (100 gram tepung sukun) nilai kadar abunya lebih tinggi dibandingkan dengan P1, P2 dan P3. Menurut Lisa, $d k k$, (2015) bahwa faktor yang berpengaruh terhadap kadar abu tepung sukun hanya suhu pengeringan, karena semakin tinggi suhu dan lama pengeringan maka kadar abu tepung juga akan semakin tinggi, seperti yang dikemukakan oleh Lisa, $d k k$, (2015) bahwa dengan bertambahnya suhu pengeringan maka kadar abu akan cenderung meningkat. Seperti diketahui pula dari wujudnya, produk tepung sukun memiliki warna yang lebih gelap dibandingkan tepung terigu. Kadar abu yang baik 
pada suatu produk makanan adalah kadar abu yang rendah, karena seperti yang diketahui tubuh hanya membutuhkan protein dan karbohidrat sebagai suplai makanan. Jika mineral yang terkandung di dalam bahan pangan tinggi maka tinggi pula kadar abu yang dihasilkan (Pinasthi, 2017).

Kandungan abu dapat digunakan untuk memperkirakan kandungan dan keaslian bahan yang digunakan (Maulana, 2016). Penentuan kadar abu total berguna sebagai parameter nilai suatu produk makanan karena dengan meningkatnya kadar abu maka meningkat pula mineral yang terkandung dalam produk kue semprong tepung sukun.

Kadar abu merupakan zat-zat anorganik ataupun mineral-mineral yang terdapat pada seuatu bahan, penentuan kadar abu dan komposisinya tergantung pada jenis bahan dan cara pengabuan. Menurut Maulana, (2016) penentuan kadar abu total dapat digunakan untuk menentukan baik atau tidaknya suatu pengolahan.

\section{Kadar Lemak}

Data hasil analisis varians kadar lemak pada kue semprong tepung sukun (Artocarpus altilis) yang berbeda disajikan pada gambar 4 .

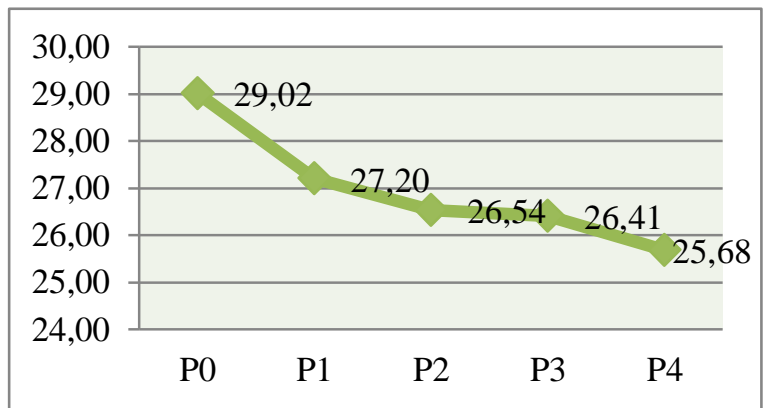

Gambar 4. Diagram Garis Rata-rata Kadar Lemak Kue Semprong

Berdasarkan hasil analisis varians kadar lemak kue semprong menunjukkan bahwa ratarata kadar lemak dari setiap perlakuan P0 sampai P4 dengan nilai berkisar antara $29.02 \%$ sampai $25.68 \%$, dengan ini bisa dilihat bahwa kadar lemak kue semprong mengalami penuruanan berarti semakin banyak pensubtitusian tepung sukun terhadap kue semprong semakin rendah pula kadar lemaknya. Berarti tepung sukun memiliki kadar lemak lebih rendah yaitu 2.72 gram dibandingkan tepung terigu untuk kandungan kadar lemak tepung sukun dapat dilihat pada tabel 3. Dari hasil uji BNT 5\% menunjukan bahwa P2 (50 gram tepung sukun) tidak berbeda nyata terhadap P3 (75 gram tepung sukun), tetapi berbeda nyata terhadap P1 (25 gram tepung suun) dan P4 (100 gram tepung sukun), sedangkan P4 berbeda nyata terhadap P1. Hal ini dikarenakan, kadar lemak tepung sukun memang rendah dibandingkan tepung terigu walaupun dipengaruhi juga oleh penambahan telur dan margarin dimana setiap perlakuan menggunakan takaran yang sama.

Lemak adalah zat makanan yang penting untuk menjaga kesehatan tubuh manusia dan merupakan sumber energi (Serlahwaty, $d k k$, 2015).

\section{Kadar Protein}

Berdasarkan hasil analisis setiap perlakuan yang telah dilakukan diperoleh nilai rerata kadar protein berkisar antara $2.91 \%$ sampai dengan 5.36\%. Gambar 5 menujukkan rerata kadar protein yang terdapat pada kue semprong.

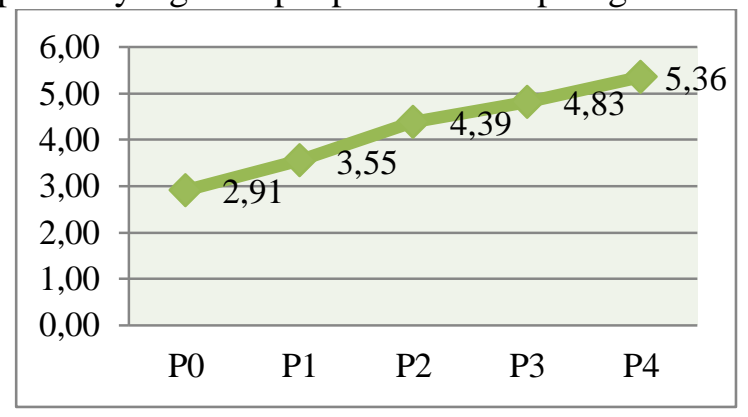

Gambar 5. Diagram Garis Rata-rata Kadar Protein Kue Semprong

Kadar protein yang diperoleh berkisar antara 2.91-5.36\% hasil kadar protein tersebut lebih rendah dari standar kadar protein mutu kue kering yang diisyaratakan SNI 01-2973-1992 yaitu sebesar $6 \%$. Hal ini menunjukan kadar protein kue semprong sudah memenuhi standar SNI.

Berdasarkan Gambar 5 menunjukkan terjadinya peningkatan kadar protein seiring dengan penambahan bahan baku tepung sukun dari setiap perlakuan, yaitu nilai kadar protein tertinggi pada kue semprong subtitusi tepung sukun terdapat pada P4 (100 gram tepung sukun), sedangkan kadar protein terendah pada kue semprong subtitusi tepung sukun terdapat pada P1 (25 gram tepung sukun), dari hasil uji BNT 5\% menunjukan bahwa P1 (25 gram tepung sukun), berbeda nyata terhadap P2 (50 gram tepung sukun), P3 (75 gram tepung sukun) dan P4 (100 gram tepung sukun), hal ini dikarenakan kadar protein kue semprong terdenaturasi pada saat proses pengovenan menggunakan suhu panas yang tidak stabil. Menurut Yuningsih (2017), denaturasi protein adalah terjadinya kerusakan struktur primer (ikatan peptida), 
sekunder, dan kuartener. Protein dapat mengalami koagulasi apabila dipanaskan pada suhu $50^{\circ} \mathrm{C}$ atau lebih, koagulasi ini terjadi bila larutan protein berada titik isoelektrisnya.

Protein merupakan zat gizi yang sangat penting, karena yang paling erat hubungannya dengan proses-proses kehidupan. Salah satu peran pentingnya adalah sebagai biomakromolekul. Menuruit Rosaini, dkk, (2015) Protein merupakan salah satu makronutrisi yang memilki peranan penting dalam pembentukan biomolekul. Protein merupakan makromolekul yang menyusun lebih dari separuh bagian sel.

\section{Kadar Karbohidrat}

Data hasil analisis varians kadar karbohidrat pada tepung sukun (Artocarpus altilis) yang berbeda disajikan pada Gambar 6

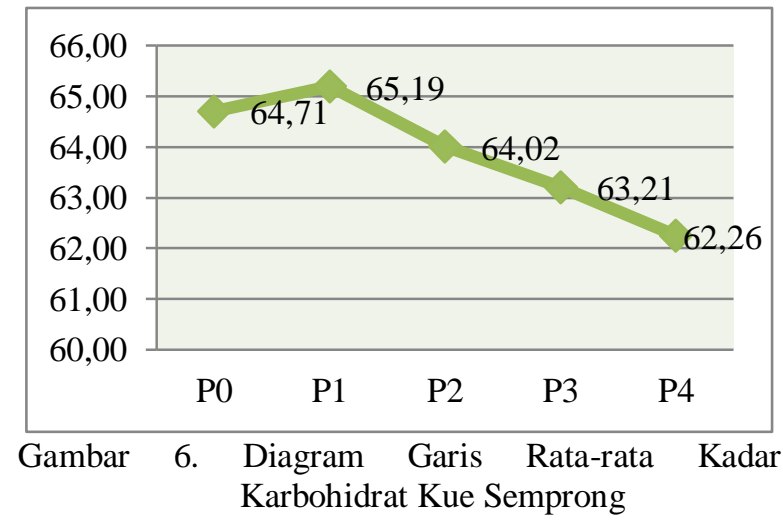

Berdasarkan hasil penelitian, kadar karbohidrat by difference kue semprong dari setiap pelakuan P0 samapai P4 berkisar antara $64.71 \%$ sampai dengan $62.26 \%$. Kadar karbohidrat terendah terdapat pada P4 62.26\% sedangkan kadar karbohidrat tertinggi terdapat pada P1 yaitu 65,19\%. Analisis juga menunjukkan bahwa pada kadar karbohidrat cenderung mengalami penurunan seiring dengan formulasi pensubtitusian tepung terigu dengan penambahan tepung sukun. Hal ini menyebabkan karena kadar karbohidrat pada tepung sukun dan tepung terigu berbeda, dan dapat dikatakan bahwa kandungan karbohidrat pada tepung sukun lebih tinggi yaitu $78.9 \%$ dibandingkan dengan tepung terigu $77.3 \%$, tetapi pada perlakuan P4 (100 gram tepung sukun) kadar karbohidratnya lebih rendah dari P0 (100 gram tepung terigu), ini dikarenakan adanya kandungan pati pada tepung terigu yang lebih tinggi dari pada tepung sukun. Pati merupakan salah satu jenis karbohidrat, pati masuk dalam golongan polisakarida yang terkandung dalam serealia dan umbi-umbian.
Selain itu ada beberapa hal yang mempengaruhi kadar karohidrat pada kue semprong dan tepung sukun yaitu proses pembuatannya anatara lain pengeringan, dan pemanggangan sesuai dengan pernyataan Khotijah, (2016) bahwa pengeringan bahan pangan akan mengubah sifat-sifat fisik dan kimia bahan pangan tersebut.

\section{Kesimpulan dan Saran}

\section{Kesimpulan}

Berdasarkan hasil penelitian yang telah dilaksanakan disimpulkan bahwa, subtitusi tepung terigu dengan tepung sukun (Artocarpus altilis) mempengaruhi mutu kimia pada kue semprong. Hasil penelitian kue semprong tepung sukun yang paling terbaik terdapat pada perlakuan P2 (50 gram tepung sukun +50 gram tepung terigu) dengan nilai rata-rata kadar air $3.60 \%$, kadar abu $1.20 \%$, kadar lemak $26,54 \%$, kadar protein $4.39 \%$, dan kadar karbohidrat $64.02 \%$.

\section{Saran}

Perlunya pengembangan penelitian lebih lanjut seperti daya simpan untuk memodifikasi teknologi pengolahan pangan baru yang berasal dari tepung sukun (Artocarpus altilis).

\section{Daftar Pustaka}

Asnani, A., Rahim, A., \& Ifall, I. 2019. Karakteristik Fisik, Kimia Dan Organoleptik Mie Kering Pada Berbagai Rasio Tepung Bonggol Pisang Kepok. Agrointek, 13(1), 82-90.

Harijono H., Susanto W. H., dan Ismet F. 2012. Studi Penggunaan Proporsi Tepung (Sorgum Ketan Dengan Beras Ketan) Dan Tingkat Kepekatan Santan Yang Berbeda Terhadap Kualitas Kue Semprong. Jurusan Teknologi Hasil Pertanian, Fakultas Teknologi Pertanian, Universitas Brawijaya.

Karim Y. O. 2016. Kadar Air dalam Bahan Pangan.http://yanialkarim.blogspot. com/2016/07/kadar-air-dalam-bahanpangan.html. Diakses pada tangal 11 Maret 2019.

Khotijah S. 2016. Kadar Karbohidrat Dan Organoleptik Mie Basah Tepung Biji Nangka Dengan Penambahan Kulit Buah Naga Sebagai Pewarna Alami [Naskah Publikasi]. Program Studi Pendidikan 
Biologi, Fakultas Keguruan Dan Ilmu Pendidikan, Universitas Muhammadiyah Surakarta.

Lisa M., Lutfi M., Susilo B. 2015. Pengaruh Suhu dan Lama Pengeringan terhadap Mutu Tepung Jamur Tiram Putih (Plaerotus ostreatus).Jurnal Keteknikan Pertanian Tropis dan Biosistem.Vol. 3, No 3.270-279.

Liviawaty E., Rostini I., dan Pratama I. R. 2014.Karakteristik Biscuit Dengan Penambahan Tepung Tulang Ikan Jangilus (Istiophorus sp). Fakultas Perikanan Dan Ilmu Kelauatan, Universitas Padjadjaran. Jurnal Akuatika vol V, No. 1, Hal 30-39. ISSN 0853-2532

Lubis Z., Sitohang K. A. K., dan Lubis L. M. 2015. Pengaruh Perbandingan Jumlah Tepung Terigu dan Tepung Sukun Dengan Jenis Penstabil Terhadap Mutu Cookies Sukun.Jurnal Ilmu dan Teknologi Pangan, Vol. 3, No. 3, Hal. 305-315

Maulana A. 2016. Analisis Parameter Mutu dan Kadar Flavonoid pada Produk Teh Hitam celup [Tugas Akhir]. Program Studi Teknologi Pangan, Fakultas Teknik, Universias Pasundan, Bandung.

Mutmaianh F., Rahardian D., Amanto B. S. 2013.Kajian Karakteristik Fisikokimia Tepung Sukun (Artocarpus communis) Termodifikasi dengan Variasi Lama Perendaman dan Kondentrasi Asam Asetat. Jurnal Teknologi Pangan. Vol. 2 No. 4. ISSN: 2302-0733.
Pinasthi S. T. 2017. Bab IV Pembahasan. Reposioy.uksw.edu/bitstream/12345678 9/1487/4/T1_512011033_BAB\%20IV.pdf. Diakses pada tanggal 13 Maret 2019.

Prastyono, Setiadi D., Adinugroho H. A., dan Kartikawati N. K. 2014. Pengembangan Teknik Budidaya Sukun (Artocarpus altilis)Untuk Ketahanan Pangan.Jakarta : IPB Press.

Purwanita R. S. 2013. Skripsi Eksperimen Pembuatan Egg Roll Tepung Sukun (Artocarpus altilis) Dengan Penambahan Jumlah Tepung Tapioka yang Berbeda.Jurusan Teknologi Jasa dan Produksi, Fakultas Teknik, Universitas Negeri Semarang.

Rakhmah Y. 2012. Studi Pembuatan Bolu Gulung Dari Tepung Ubi Jalar (Ipomoea Batatas L) [Skripsi]. Program Studi Ilmu Dan Teknologi Pangan, Jurusan Teknologi Pertanian, Fakultas Pertanian, Universitas Hasanuddin Makassar

Serlahwaty D., Syarmalina, Sari N. 2015.Analisis Kandungan Lemak dan Protein terhadap Kualitas Soyghurt denga Penambahan Susu Krim. Fakultas Farmasi, Universitas Pancasila. Jurnal Berkala Ilmiah Kimia Farmasi. Vol. 4 No. 2.

Standar Nasional Indonesia. 1992. Kue Kering. SNI: 01-2973-1992. Dewan Standarisasi Nasional.

Yunigsih S., Rupiah N., Nulhakim R. L. 2017. Denaturasi Protein. Jurnal Denaturasi Protein.Program Studi Ilmu dan Teknologi Pangan, Universitas Garut. 